\title{
Tropes as Rhetorical Devices in the Presidential Campaign in Croatia
}

\section{Anita Runjić-Stoilova}

\author{
Assistant Professor, Faculty of Humanities and Social Sciences, University of Split, Croatia
} Email: arunjic@ffst.hr

\section{Davor Stanković}

I to nije sve! Creative Agency, Zagreb, Croatia Email: davor42@gmail.com

\section{Doi:10.5901/ajis.2016.v5n1p23}

\begin{abstract}
In this paper authors analyse figurativeness in speeches of presidential candidates during the presidential campaign in Croatia in 2009/2010. This paper explores how the usage of rhetorical tropes in speeches of presidential candidates influenced the election results and number of votes of each candidate. In contrast to the other figures of speech, tropes are more closely related to content than to form or structure. Rhetorical tropes fulfil many different purposes in political discourse, especially in regard to positive political self-presentation and negative political other-presentation. Rhetorical tropes analysed in this paper are divided according to the Burke's (1969) classification: metaphor, metonymy, synecdoche and irony. The metaphor is analysed and outlined as one of the master tropes. In Croatian political discourse metaphor is most commonly drawn from the sports and military terminology, for example, the expressions "political competition", "presidential race", "leading the political battle". Authors compare usage of rhetorical tropes with the success of presidential candidates in the above mentioned presidential campaign
\end{abstract}

Keywords: Figurativeness, Rhetorical Tropes, Metaphor, Metonymy, Synecdoche.

\section{Introduction}

\subsection{Figures and their Classification}

Within the antique rhetorical tradition, in the part concerning speech configuration, central place doubtlessly belongs to the study of types of figures. According to the traditional rhetoric, figures don't tell us more than its non-figurative correlates but they tell us something in a more alive, more charming and more refined way. Figures are just semantically equivalent substitutions for simple words. Therefore, by using them, poetic language acquires quaintness but not informative value as well (Benčić, 1995). Since Cicero and Quintilian, definitions of figures refer to the concrete usage in rhetoric because they included speaker (ethos), audience (pathos) and speech (logos). So the figure was implying every speaker's influence on the audience by using terms or arguments on unusual, unpredictable and extraordinary way (Škarić, 2000:109). Accordingly, we can define rhetorical figures as a deviation from the ordinary mode of expression. Very often figure is considered to be deviation from ordinary language, therefore is also called speech ornament (Aristotle, 1989).

There is no standard antique classification of figurative devices. Probably one of the reasons was the unresolved dispute between rhetoricians and grammarians about the competence on figures. With the general predominance of rhetoric stored in logos, even in the Middle Ages there was rivalry between the rhetoric of place (inventio), close to the dialectics, and the rhetoric of figure (elocutio), close to the grammar. In fact, two comprehensions of logos are conflicted. The first one, inherited from Aristotle, gives the advantage to the human intellect, reasoning and invention, supported by memory. The second one is more religious - it sees the possibility of expressing the Divine in the possibility of different forms of the word (Meyer et al., 2008). The phenomenon of rhetorical figures being a part of grammar is not restricted only to the Middle Ages. From Medieval grammar to some of today's rhetoric, the idea of rationality is present in linguistic expressions and in the way we speak no matter what we want (Meyer et al., 2008:70). It is very important to understand the basic principles of classification that stood for centuries. The first great distribution of figures, as Meyer (Meyer et al., 2008) claims, is based on the difference among the speech material, content and described reality. The speech material 
is made of words and their order. This results with figures of speech, related with the sonority in language and also with figures of construction, related with order in a sentence. The speech content are arguments and meanings that speaker uses to persuade the audience. Those many shifts of meanings are called figures of meaning. Ultimately, the speaker can aim at the outward context of his speech and described reality by creating the figures of thoughts. Therefore, figures can be classified as tropes (figures that change the meaning of one word - metaphor, metonymy, synecdoche...), figures of meaning (figures that change the meaning of a word group - oxymoron, hyperbole...), figures of words (figures that refer to the sonority of words - alliteration, rhyme...), figures of construction (figures that refer to word order in the sentence - gradation, repetition...), figures of thoughts (figures that deal with the speech referent - irony, allegory...).

The second great distribution of figures according to Beker (1997:63) is based on the difference between tropes and figures, and there the reality, language and thought are more closely connected. Quintilian (1986) speaks about trope when the speaker is using a separate word and about figure when he is using the whole expression. What they have in common is the change from the simple way of expression by using the speech ornament. He concludes that we speak about trope when the word transfers its first meaning to another, and we speak about figures when the word turns from ordinary way of expression. He has counted twelve different tropes: metaphor, metonymy, synecdoche, antonomasia, onomatopoeia, catachresis, metalepsis, epithet, allegory, periphrasis, hyperbaton and hyperbola (Quintilian, 1986).

The affiliation of the individual figure to the category of figures isn't clear even today. The most common classification is Quintilian's, as we already pointed out, the simple division on tropes and schemes (figures). The term trope indicates the turn (Greek substantive tropós means turn or direction), and the term scheme in Greek means body position, posture or attitude, especially speaker's. Schemes are acts within the linguistic field; tropes are dealing with changes within the field of content. There are different ways to classify tropes; one of these classifications divides tropes into five groups (Ivas, 2004). The first group of tropes refers to substitution of similar meaning (comparison, metaphor, personification, and antonomasia); the second type of tropes refers to causal, spatial or some other relations (metonymy and synecdoche); the third group are metaphorical-metonymical tropes (periphrasis and descriptions of bodily movements and postures); the fourth group of tropes refers to opposition of meaning (irony); and the fifth group are tropes that include turn of meaning by intensity (hyperbola).

Concerning the relationship between what is said or written and what is meant, Heinrich Lausberg (1998:64-79) distinguishes two types of tropes. The first type - tropes of shifting boundaries consist of moving the borders of neighbouring semantic fields or the borders within one and the same semantic field. These tropes are determined by a relationship of inclusion or connection between what is said or written and what is meant. They are, accordingly, divided into two subcategories. Periphrasis, litotes, hyperbole, emphasis, antonomasia, and synecdoche are assigned to the first subcategory. They are constituted by shifting the boundary within a semantic sphere. The second subcategory involves a relationship of adjacency. It is prototypically represented by metonymy. The second type of tropes is called leaping tropes. In comparison to tropes that involve shifting boundaries, leaping tropes are grounded on a leap from one semantic sphere to another that is not adjacent to the first one. Traditionally, metaphor, allegory, and irony are considered to be leaping tropes. Their intended meaning is to be found in a semantic domain that clearly differs from what is actually said or written. In concrete rhetoric analysis a clear distinction between the two types of tropes is not always feasible. Nowadays, it is almost common place in modern rhetoric, linguistics, language, philosophy, and cognitive science that all areas of language are pervaded with tropes, and that tropes function as elementary cognitive principles that shape and structure human perception and thinking. Tropes are no longer exclusively associated with the stage of elocutio; rather they are also related with the stage of inventio and, of course, to processes of the speech's reception or apperception (Reisigl, 2006:598).

Only metaphor, more than any other expression, contributes to clarity, satisfaction and dignity of the style. Even Aristotle listed basic types of transfer within metaphor: 1) genus to species; 2) species to genus; 3) species to species; and 4) by analogy (Aristotle according to Beker, 1997: 22). The first and the second type today is considered to be metonymy, i.e. synecdoche, while the third and the forth type are considered to be real metaphor. He ascribes metaphor primarily as decorative language supplement.

\subsection{Tropes in Political Discourse}

Political discourse is full of tropes related to three political dimensions of form, content and process. In all fields of political action politicians employ those figures of speech as effective rhetorical means of constructing, representing, and transforming political reality, as well as means of political persuasion. Fields of action (Reisigl, 2006:598) may be understood as frameworks of social interaction. According to Reisigl (2006) tropes fulfil many different purposes in 
political discourses, especially in regard to positive political self-presentation and negative political other-presentation. They help to invent or construct a political reality, to reduce complexities by simplistic categorization and imaginary representation of political reality, to vivify, personify, and illustrate abstract or unclear political ideas, to selectively foreground specific traits of political entities or reality sectors, and to back ground or hide specific political aspects, actors, or actions. When looking at the interpersonal metafunction of language, these tropes are employed to promote the identification with single or collective political actors (e.g. leaders, parties, states and nation; in this paper leaders), as well as with their political aims and ideologies, to promote in-group solidarity, to justify, legitimize specific political actions or their omission etc.

We can say that studying the metaphor and tropes in general, lies in the intersection of three areas of humanistic knowledge: cognitive linguistics, discourse analysis and rhetoric. Cognitive metaphor, most important in researches of Lakoff $(1980,1992)$, highlights the relation between political metaphor and comprehension, discourse analysis discusses the metaphor as a tool of politics and authority, and finally, rhetoric emphasises the role of metaphor in communication. So, metaphor becomes the product of language, thinking, public and culture.

\subsubsection{Metaphor}

Metaphor (from the Greek metaforá meaning translation) is considered to be the substitution of names or the transfer of names from one thing to another and the transfer of meaning from one word to another. The most of the classical rhetoricians insist on ornamental function of metaphor, but nowadays some of the theorists assert their abstractness. Usually, in metaphor an interrelation between two different subjects has been recognized (subject A and subject B) in order to emphasize unexpected similarity between them. Metaphor establishes a similarity between two different semantic domains. Many types of metaphor occur in political discourse. Some metaphors transform inanimate objects into animate ones, some turn the quality of animate objects into other animate objects, some transform abstract entities into concrete etc. According to Reisigl (2006) many metaphors in political discourse transfer aspects from the economic to the political domain and many from the domain of private life and family into public life. Various metaphors project elements from the domains of sports into the political domain.

\subsubsection{Metonymy}

Metonymy (from the Greek metonimía meaning renaming, name change) can be interpreted not as shift by similarity but by any other experiential connection (relation): spatial, temporal, causal, consequential, symbolic. Since both objects are in the same spatial-temporal field, metonymy stays within one semantic field. Metonymy was, as it has already been said, known in the Antique rhetoric. But then, its language usage was perceived as a rhetorical figure which contributes to the style of the writer. In the twentieth century metonymy was studied in rhetorical and literary texts, but also in everyday language as a lexical metonymy. In that context there are some definitions of metonymy by Simeon (1969) and Crystal (1987) as a figure constituted by using one name of the object (referent) instead another which is related with the first one. Already in the Antique rhetoric, metonymy, was in contrast to metaphor, described according to the relationship between the two neighbouring conceptual fields like: 1) the name of a product stands for the cause or author, 2) the name of an objects stands for the user of the object, 3) the name of a place stands for the person living on the place, 4) the name of a place stands for an action performed at the place or an event located at the place, etc. Lakoff and Johnson (1980:35) write that with metonymy "we are using one entity to refer to another that is related to it“.

\subsubsection{Synecdoche}

Synecdoche (from the Greek: understanding one thing with another) is turn of meaning within one and the same semantic field. The particularizing synecdoche is constituted by a representative relation that consists of a semantically narrower concept standing for a semantically broader concept. The three main subcategories of this type of synecdoche are pars pro toto (i.e. the part stands for whole), singularis pro plurale (i.e. the singular stands for plural), and the species pro genus (i.e. the species stands for the genus). The generalizing synecdoche is established by a semantically broader concept that represents a semantically narrower one. The three principal subcategories are totum pro parte, pluralis pro singulare, and genus pro species (Reisigl, 2006:603). 


\subsection{Semantic Fields of Tropes}

Language can be presented as a net of multiple semantic fields. Term semantic field primarily describes the word's reality, not some higher or lower linguistic levels. Semantic field means systematized totality of actual and potential meanings which enter into the word in different ways. Semantic field is consisted with basic (central, core) meanings and peripheral (additional) meanings. Every semantic field has its specificity; their boundaries are not visible (Užarević, 1995:105-106). Tropes can be defined by qualitative turn of meaning inside one or more semantic fields. Part or segment of one semantic field determines extent of the whole field. That means that periphery arrives in the centre of the field, from where it redefines itself. After identifying the part with the whole, semantic fields are merging into new upper level. Allegorical meaning refers that the meaning is transferred either from periphery to the centre or from one semantic field to another. If the turn of meaning from part to whole is taking place within one semantic field, it's considered to be a metonymy. If the turn of meaning is from one semantic field to another, it's considered to be a metaphor. The bigger the distance between semantic fields is, the metaphor is more surprising, more original, more shocking.

According to Master Metaphor list (Lakoff et al., 1991) most of often used semantic fields are those of war and sport. These concrete scopes are used to conceptualise abstract scope of politics. For example, when elections are being compared with war, presidential candidates are often seen as two sides in a war, country are taking place becomes a battlefield, elections a battle and arguments in a political debate are used as munitions. The elections are often being compared to a boxing match in which one candidate pushes the other out of the ring, or to a sport race or game where candidate accuse each other of unfair play. The country is then being given human characteristics as it can make decisions, have friends, etc.

\section{Purpose and Hypothesis}

The purpose of this research was to see the amount and the diversity of rhetorical tropes in presidential campaign in Croatia in 2009/2010. The purpose was also to determine whether the presidential candidates differ according to the usage of tropes and at the end to find out whether the usage of tropes influences candidates' success in presidential election. The hypothesis is that the tropes are used in great extent and metaphor is the most often used one. The prediction is that the presidential candidate who uses more tropes will get more votes.

\section{Materials and Methods}

Three presidential debates in December 2009 and January 2010 have been analysed for this purpose. Television debates were held between two presidential candidates and were performed on three Croatian national televisions: HTV, RTL and NOVA TV. These debates had metaphorical titles like The Battle for Pantovčak (HTV), RTL Duel and Presidential race (NOVA TV). The candidates were Ivo Josipović (as the candidate of the SDP - Social Democratic Party) and Milan Bandić (as an independent candidate), and each of them spoke for the same amount of time. In that what follows, so called tropology is outlined with the examples of tropes from three televised presidential debates. Because of its simplicity, our tropology is based on the Burke's division on four master tropes (Burke, 1969): metaphor (including personification and allegory), metonymy, and synecdoche (including antonomasia as a special form of synecdoche). The fourth alleged master trope, irony will be dropped in this research, as its character is very different from that of the three basic tropes. It is much more heterogeneous, and often involves the prosodic, gestural, or facial-expressive dimension of language. Also, in this research no attention has been paid to other linguistic occurrences traditionally also apostrophized as tropes: periphrasis, litotes, hyperbole, and emphasis. As rhetorical phenomena, they do often derive from the three basic tropes. Periphrasis, for instance, can linguistically be realized as antonomasia, synecdoche, metaphor, allegory metonymy and so forth.

\section{Results and Discussion}

The results show that there were 261 tropes used in these presidential debates. It wasn't always easy to determine the difference among tropes, especially metaphor and metonymy. 


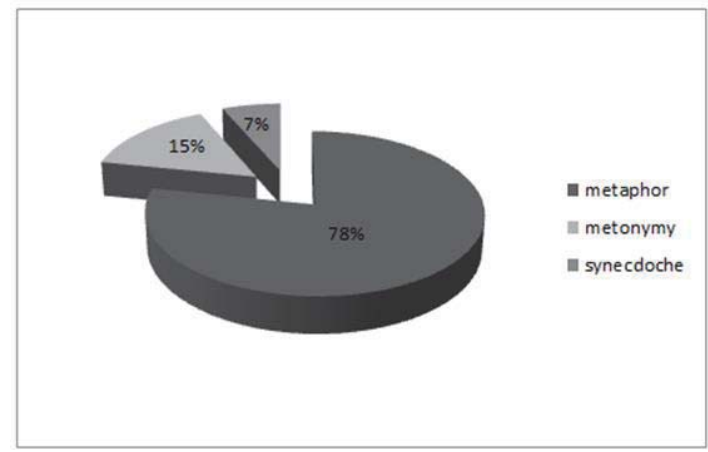

Figure 1. The percentage of the usage of tropes

Figure 1 shows the relation in percentage among the usages of each group of tropes: metaphor, metonymy and synecdoche. As it was expected, metaphor turned out to be the most frequently used trope and synecdoche the least frequently used one. Of all tropes, metaphors surely get most attention in the analysis of political discourse. It is interesting to see some examples used by both presidential candidates.

Josipović used the following metaphors:

- The elections are a festival of democracy. In this metaphor two semantic fields are brought together, abstract concept of politics (elections) is connected with entertainment, so this concrete concept may be closer to the public.

- I am sure that the light will win on January 10th. The light is often a symbol of positive political changes. So, this metaphor has positive connotations implying that if voters choose Josipović on the day of the election (January $10^{\text {th }}$ ) there will be light. It is a kind of stereotype - light versus dark.

- Vote for Croatia that is going to be your mother and not your stepmother! Here the metaphor transfers inanimate object, i.e. abstract entity (country Croatia) into animate one (mother). This is the personification of Croatia, used to give Croatia a human form. This is the domain of private life and the figures of mother and stepmother are very clear.

- Croatia will become a shiny star of European Union. This metaphor predicates onto inanimate object (abstract entity - Croatia) the quality of another inanimate object - shine of a star as a positive characteristic. And not any star, but the star from the flag of the European Union that is the goal of Croatia. So, voters can identify or feel solidarity with this politician.

Bandić uses the following metaphors:

- I have been living in Big Brother for 10 years. Here again two semantic fields are brought together, election and entertainment. But here the message is also the transparency of candidate's work.

- We have to pull Croatia out of the economic mud. Economically hard situation has been described with another inanimate term that makes the public perceive the situation as even harder than it is.

- My dear colleague Josipović is a president working on a remote control. Here the animate object (human being) transforms into inanimate one. Bandić wants to discredit the opponent by saying that he is just a puppet on a string. He is doing everything that his political party tells him.

- The country should lose some weight. It has become too fat. The metaphor of using the words connected with weight and appearance is used to describe the large amount of problems that have not been solved during the past few years.

Josipović used different metonymies in his speech:

- Dayton opened the question of equality. The name of the place stands for an agreement that was achieved there. Also Dayton is humanized in this sentence, so it is also a metaphor.

- I will make sure that her report doesn't end up in some drawer. Drawer is used in a sentence to denote a place where unimportant papers are put. That way it stays within the same semantic field, only place is used instead of the action.

- Catholic Church has rights to express their own meaning. In this metonymy the name of an institution stands 
for actions performed within the institution.

Bandić used these metonymies:

- The safety of Croatian sky must be arranged. Here the metonymy is Croatian sky which represents a place where Croatian airplanes are flying. So, in fact, Croatian air forces must be arranged.

- The decision was made by the White House. The name of the institution (the White House) stands for representatives of the institution (American Government).

- When I come to Pantovčak, I will demand that they change the law. In this sentence Pantovčak (a district of the city of Zagreb) stands for the representative who lives there (Croatian president).

Some of Josipović's synecdoches are:

- It is important that everyone can return to their fireplaces. This synecdoche is particularizing one - pars pro toto, where a part (the fireplace) stands for the whole (the home).

- I think it is very important to have contact with the world. This is generalizing synecdoche because the world means every country and every government.

- The income of the campaign gives one number, and the number of posters on the street gives another. This is particularizing synecdoche where part (number of posters) stands for whole (expenses of the campaign).

Bandić's synecdoches are:

- I will return dignity and pride to a Croatian man. This is particularizing synecdoche because he uses singular for plural, as every Croatian man stands for all Croatian people.

- Representatives of Bosnian people should put their heads together. This is also particularizing synecdoche because the term heads are used instead the term person.

- I am not a candidate for English Prime Minister. Here the term English Prime Minister stands for every occupation that requires the knowledge of English language. In order to understand this figure it must be mentioned that this presidential candidate is trying to turn his inability to speak English into one of his virtues.

Metaphor is not just a poetic figure used by speakers in order to make their speech more elegant. As Lakoff (1980) puts it, the main function of the metaphor is to understand one type of experience thanks to the qualities that a part of some other experience has. Metaphorical overlapping move from the scope of concrete experience to the scopes we experience as abstract. Semantic fields found in this research are: sport, war, medicine, construction, nature, food, traffic, family, mathematics. Because of the limit of extent, only those semantic fields with more than ten examples of metaphor are shown.

Semantic field of sport: The final game is on January 10th, and the game is played for 90 minutes. Croatian economy can jump over that obstacle. Former Yugoslav countries will still have to sit on the bench for some time. I think it would be appropriate not go below the belt.

Semantic field of war: Same target, same distance. Don't vote for Croatia that is trying to divide us and send us all back to the trenches of history. We should start a battle against criminality and corruption. Croatia has to reorganize her troops.

Semantic field of medicine: New Croatian president has to be able to unite Croatian tissue that has been torn apart. Corruption is a cancer of society. I don't think being a religious man is a handicap. My program is supported by the Left and the Right as it is obvious from the analysis of their blood.

Semantic field of construction: They are the ones who tried to demolish Prime Minister Kosor. I have been building SDP. Good relations are a foundation of national security. Dayton has cemented the relations in Bosnia and Herzegovina.

Semantic field of nature: This affair is just the top of an iceberg in front of us. The roots of our values. We have to pull Croatia out of the economic mud

Semantic field of food: The country should lose some weight. It has become too fat. Everybody get their piece of cake. We are in the same pot. We must bite the sour apple.

Semantic field of traffic: This is our last chance to jump into the train to Europe. The way of peace and democracy leads through Zagreb. Croatia is sailing toward progress.

Semantic field of family: It is important that everyone can return to their fireplaces. Vote for Croatia that is going to be your mother and not your stepmother!

What can be concluded is the dominance of the semantic field of war, sport and game. That was somehow expected, because the politics is competitive by itself, it is reduced to election's competition and finally it is a relation between the winner and the defeated one. If political speech would be analysed in other countries, cultures and languages in a similar way, results would probably be similar. Maybe there would be a different range of semantic fields in their political speech. 
At the end it is interesting to see who has been using more rhetorical tropes. According to the results that can be seen on Figure 2, presidential candidate Milan Bandić has been using more rhetorical tropes. It is necessary to say that the winner of the presidential elections in Croatia 2009/2010 and Croatian president for the period of 5 years was Ivo Josipović. The percentage of votes he got in the elections was $61 \%$, while his opponent Bandić got $39 \%$.

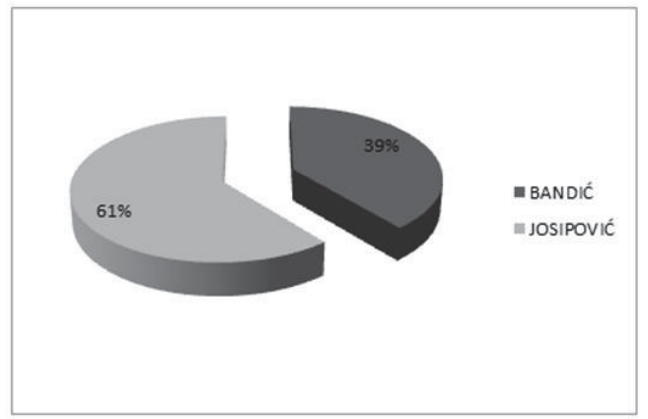

Figure 2. The percentage of tropes usage by presidential candidates

\section{Conclusion}

Presidential campaign in Croatia provided all kinds of tropes involving different semantic fields. Most commonly, in Croatian political discourse metaphor is drawn from the sports and military terminology, for example, the expressions political competition, presidential race, leading the political battle. Most frequently used trope turned out to be metaphor, followed by metonymy and synecdoche. This paper tried to explore how the usage of rhetorical tropes in speeches of presidential candidates influences the election results and the number of votes of each candidate. It turned out that the candidate who was using more tropes didn't become a president, so one can conclude that the usage of tropes does not influence candidates' success in presidential election. It is difficult to claim with certainty that less or more tropes by one or the other party or presidential candidate gives enough arguments for speaking that metaphors are conditioned by party or individual political identity. The explanation that metaphorical expression is more appropriate for the political discourse in which the usage of metaphors makes it easier for a speaker to get closer to the ordinary people is easily accepted. However, the usage of tropes is not enough for a person to be recognized as a good speaker. There is environment knowledge of someone's logic, ethics, credibility, background, appearance.

\section{References}

Aristotle (1989). Rhetoric. Zagreb: Naprijed.

Beker, M. (1997). A brief history of ancient rhetoric. Zagreb: ArTresor naklada.

Benčić, Ž. (1995). Antonomasia. In D. Fališevac \& Ž. Benčić (Eds.), Tropes and figures. (pp. 89-218). Zagreb: Zavod za znanost 0 književnosti.

Budor, K. (1995). Rhetoric and its relation to word play. In D. Fališevac \& Ž. Benčić (Eds.), Tropes and figures. (pp. 327-343). Zagreb: Zavod za znanost o književnosti.

Burke, K. (1969). A rhetoric of motives. New York: rentice-Hall, INC.

Crystal, D. (2003). A dictionary of linguistics and phonetics (5thEdition). Oxford: Blackwell Publishing.

Ivas, I. (1985). Figures of political speech. Polja/Fields, 31, 317-320.

Ivas, I. (2004). Tropes in newspaper headlines. Medijska istraživanja/Media research, 10, 9-34.

Kravar, Z. (1995). Aesthetics of tropes. In D. Fališevac \& Ž. Benčić (Eds.), Tropes and figures (pp. 75-103). Zagreb: Zavod za znanost 0 kniǰzevnosti.

Lakoff, G. (1980). Metaphor we live by. Chicago-London: The University of Chicago Press.

Lakoff, G. (1992). Metaphor and war: the metaphor system used to justify war in the gulf. In M. Pütz (Ed.), Thirty years of linguistic evolution (pp. 463-481). Philadelphia: Benjamins.

Lakoff, G., Esperson, J. \& Schwartz A. (1991). Master metaphor list. Second draft copy. Berkeley: Cognitive Linguistics Group, University of California. [Online] Available: http://araw.mede.uic.edu/ alansz/metaphor/METAPHORLIST.pdf_(October 10, 2013)

Lausberg, H. (1998). Handbook of literary rhetoric: A foundation for literary study. Leiden, Boston, Köln: Brill.

Meyer, M., Carrilho, M. M. \& Timmermans, B. (2008). History of rhetoric from the ancient Greeks to the present day. Zagreb: Disput. 
Novaković, D. (1995). Stylistic dimension of figures in ancient rhetoric. In D. Fališevac \& Ž. Benčić (Eds.), Tropes and figures (pp. 1151). Zagreb: Zavod za znanost o književnosti.

Quintilijan. (1986). Orator's education. Sarajevo: Veselin Masleša.

Reisigl, M. (2006). Rhetorical tropes in political discourse. In K. Brown (Ed.), Encyclopedia of language and linguistics (2nd Edition) (pp. 597-604). Amsterdam: Elsevier LTD.

Simeon, R. (1969). Encyclopaedic dictionary of linguistic terms. Zagreb: Matica hrvatska.

Sušac, V. (2007). Metaphor as a reflection of linguistic identity. In J. Granić (Ed.), Language and identities (pp. 589-598). Zagreb-Split: HDPL.

Škarić, I. (2000). The foundation of modern rhetoric. Zagreb: Školska knjiga.

Užarević, J. (1995). Tropes and language. In D. Fališevac \& Ž. Benčić (Eds.), Tropes and figures (pp. 105-113). Zagreb: Zavod za znanost o književnosti. 